\title{
Eating psychopathology and psychosocial impairment in eating disordered individuals - a Singapore study
}

\author{
Kah Wee $\mathrm{Ng}^{*}$, Angeline Kuek, Huei Yen Lee \\ From 2013 ANZAED Conference: Inspiring Change: Person and Context \\ Melbourne, Australia. 23-24 August 2013
}

Research has shown that eating disorders have a serious and detrimental impact on an individual's physical and mental well-being. In various studies conducted in the West, it was seen that eating disorders have a negative impact on psychosocial functioning and that individuals with eating disorders report a lower quality of life. It is interesting to note that previous studies have shown that south-east Asian individuals exhibit lower levels of body satisfaction, greater eating disorder psychopathology, and more concern about their weight compared to their Western counterparts. However, compared to Western individuals, the level of eating psychopathology and psychosocial impairment in Asian individuals is still relatively unknown. Knowledge in these domains may improve treatment and elucidate the impact eating disorders have on Asian individuals. The objectives of this study are:

a) To determine the level of eating psychopathology and psychosocial impairment in individuals with eating disorders in Singapore and;

b) To determine if there are any differences in levels of eating psychopathology and psychosocial impairment between the different eating disorders classifications.

This abstract was presented in the Understanding and Treating Eating Pathology stream of the 2013 ANZAED Conference.

Published: 14 November 2013

doi:10.1186/2050-2974-1-S1-068

Cite this article as: $\mathrm{Ng}$ et al:: Eating psychopathology and psychosocial impairment in eating disordered individuals - a Singapore study. Journal of Eating Disorders 2013 1(Suppl 1):O68.

* Correspondence: ng.kah.wee@sgh.com.sg

Department of Psychiatry, Singapore General Hospital, Singapore
Submit your next manuscript to BioMed Central and take full advantage of:

- Convenient online submission

- Thorough peer review

- No space constraints or color figure charges

- Immediate publication on acceptance

- Inclusion in PubMed, CAS, Scopus and Google Scholar

- Research which is freely available for redistribution
() Biomed Central 